\title{
To What Extent Retail Chains' Relationships with Suppliers Make the Business Trustworthy-An Empirical Study on Fast Fashion in Pandemic Times
}

\author{
Anna Dewalska-Opitek ${ }^{1, *(D)}$ and Katarzyna Bilińska-Reformat ${ }^{2}$ \\ 1 Department of Organisational Relationship Management, University of Economics in Katowice, \\ 40-287 Katowice, Poland \\ 2 Department of Marketing Management and Tourism, University of Economics in Katowice, \\ 40-287 Katowice, Poland; katarzyna.bilinska-reformat@ue.katowice.pl \\ * Correspondence: anna.dewalska-opitek@ue.katowice.pl; Tel.: +48-5014-36644
}

check for

updates

Citation: Dewalska-Opitek, Anna, and Katarzyna Bilińska-Reformat. 2021. To What Extent Retail Chains' Relationships with Suppliers Make the Business Trustworthy-An Empirical Study on Fast Fashion in Pandemic Times. Journal of Risk and Financial Management 14: 153. https://doi.org/10.3390/jrfm14040153

Academic Editor: Dan-Cristian Dabija

Received: 31 January 2021

Accepted: 24 March 2021

Published: 1 April 2021

Publisher's Note: MDPI stays neutral with regard to jurisdictional claims in published maps and institutional affiliations.

Copyright: (c) 2021 by the authors. Licensee MDPI, Basel, Switzerland. This article is an open access article distributed under the terms and conditions of the Creative Commons Attribution (CC BY) license (https:// creativecommons.org/licenses/by/ $4.0 /)$.
Abstract: The current pandemic situation has created many challenges for maintaining positive relationships between fast fashion retailers and their suppliers. In the proposed paper it is assumed that strong and ethical relationships may be beneficial for all supply chain members, especially in the era of global pandemic. Therefore, the aforementioned issues (fast fashion retailers' ethical behavior towards suppliers) constituted the subject of the paper. Our knowledge about relationships between fast retail chains and their suppliers in the times of global pandemic is relatively week. Trying to fill the gap, this paper discussed relationships between fast fashion retail chains and their suppliers' customers on the basis of literature review and case study research. Purpose: The aim of the paper was to indicate the scope of activities undertaken by retailers and addressed at suppliers by fast fashion retail chains in pandemic times. The following goals of descriptive and cognitive character were assumed in the paper: (a) Identification of the fast fashion retailers' common behavior in the era of pandemic, and (b) indication of ethical practices applied by fast fashion retail chains which are beneficial for all retail chain members, based on the Inditex example. Methodology: Based on the theoretic deliberation of retail chain relationships with suppliers in the pandemic times, qualitative research was conducted to supplement the theoretical background. The purpose of this study was to identify how fast fashion retailers maintain relationships with their suppliers in supply chains. The conducted research enabled us to reveal answers to the following research questions: What are good practices of fast fashion retailers in terms of relationships with suppliers? Can socially responsible, trustworthy fast fashion retailers stay profitable in the Covid-19 pandemic? The theoretical deliberation was based on a critical literature review. The empirical part of the paper was based on case study research. The conducted research was descriptive in nature, conducted in order to describe a particular phenomenon within its context, and was not intended to provide conclusive evidence, but to have a better understanding of the problem. A descriptive intrinsic case study was the method applied in the research. Results: On the grounds of literature studies, as well as collected information, we can state that close and ethical cooperation with suppliers, based on socially responsible relationships, are becoming a more and more important part of the strategy for commercial chains. There are companies that use any legal measures to not fulfil their obligations as contractors and avoid paying for orders completed and in production. The descriptive case study research allowed us to observe, analyze, and report good practices of fast fashion retailers in terms of relationships with their suppliers based on the Inditex example. The theoretical contribution: On the grounds of the case study, we can state that during pandemic times fast fashion retail chains have focused on the development of relationships with suppliers, which means changing from transactional to relationship marketing in cooperation strategies. Practical implications (if applicable): The paper provided intellectual input into the managerial problem of how to develop mutual beneficiary relationships between fast retail chains and their suppliers. The study suggests that fast fashion retail chains have to take into consideration growing customer expectations, which regard their cooperation's strategies toward suppliers. 
Keywords: fast fashion retail chains; relationships; suppliers; trust; Covid-19 pandemic

\section{Introduction}

The SARS-CoV-2 virus pandemic has halted the world economy and forced its complete reorganization. This situation has caused a shock, the effects of which will be experienced for a long time, both on the micro and macro scale.

Creative industries, including the fashion and design industries that are the subject of this paper, are struggling to maintain the scale of production, employment, and financial liquidity, preserve intellectual property rights, and adapt to the e-commerce world. In the situation of an uncertain future, business has been faced with new challenges, but also opportunities. This has clearly become apparent in the business ecosystem, in the spiral of the fashion sector which has been driven for generations by consumer desire for design, and business thirst for profit.

The main problem undertaken in this paper results from strong bargaining power of retailers, which makes these companies leaders of channels of distribution. The aim of the paper was to indicate the scope of activities undertaken by retailers and addressed at suppliers by fast fashion retail chains in pandemic times as well as presenting the best business practices in the sphere of cooperation with suppliers. The research question concerned the problem of relationships between them and their suppliers. The used method was case study research. Analyses included in the paper concerned the period between March and September 2020 that was the period of the outbreak of the global pandemic (time range). The presented results of the conducted analyses concerned international environment (spatial range).

The originality of the papers lies in the indication of best business practices regarding the cooperation strategies which are implemented by fast fashion retail chains. In addition, the chosen period of conducted analysis makes the topic interesting and current. In a difficult business environment, implementation of good business practices toward suppliers is not a common practice.

The contribution of the paper lies in presenting the change in the approach to suppliers. On the grounds of the case, we can state that during pandemic times, fast fashion retail chains have focused on the development of relationships with suppliers, which means changing from transactional to relationship marketing in their cooperation strategies.

\section{Relationships between Retail Chains and Suppliers-Relationship Paradigm Approach}

The policy of commercial chains (including fast fashion retail chains) towards suppliers is currently gaining particular importance as a source of permanent competitive advantage. According to the theory of transactional costs, retailers look in this sphere for such solutions that should allow them to pursue a flexible and competitive policy of sale. At the same time, they aim at establishment of not only their competitive advantage, but the whole channel of supply, because in this way the market position of all its participants is strengthened.

One of the most popular definitions explains the strategy of cooperation as the relationship between the parties that is not definitely defined in the form of a detailed contract strictly determining all the rights and obligations of partners (Hyvonen 1983). The strategy of cooperation determines long-term goals of an enterprise that correspond to the general direction of activity, and also show the allocation of resources that are necessary for accomplishment of assumed goals (Bensaou 1992). Growing demands of customers and intense competition on the fast fashion market are the reasons for the introduction of changes in the approach to the comprehensive strategies of retail chains (Dewalska-Opitek and Bilińska-Reformat 2016). Customers and suppliers, and in particular the establishment of relationships with customers and suppliers that allow them to achieve competitive advantage, are the key elements of this strategy (Wathe and Heide 2004; De Wulf et al. 
2001). The importance of buying function is growing in the period of crisis (as well as in the times of the global pandemic) when enterprises are searching for the sources of cost reduction. It seems that in the case of global fast fashion retail chains, the stage of buying oriented only towards products is already beyond these organizations. These enterprises realize that the activity consisting of making a purchase is associated both with functional spheres that form a chain of values as well as with external surroundings, i.e., suppliers that can contribute to the establishment of permanent competitive advantage. This is why they are indicated as partners that in practice make it possible to form a competitive market offer (Chen 2009; Mentzer et al. 2000).

The approach to managerial activity in retail trade is undergoing dynamic changes in the time of the pandemic. We should emphasize here the approach assuming that the retailer actually offers for sale a product that is everything, both good and bad, which is obtained within exchange. It is a combination of tangible and intangible qualities, including profits or functional, social, and psychological benefits (Dibb et al. 2003). According to this approach, a retailer offers a complex product for sale. The emergence of an additional category within instruments influencing the customer, namely relationships with the customer in shaping customer loyalty, proves changing of attitudes to marketing activity in retail trade. In addition to transactional attitude, a relationship attitude there occurs (Gummesson 1997).

Relationship marketing is certainly the trend of activities conducted, together with traditional methods of influencing customers by chains. However, increase in customers' awareness brought by access to knowledge about how chains treat their suppliers, whether they observe the rights of third world countries, and/or how they are oriented towards their workers and suppliers, certainly influence the development of the concept of relationship marketing.

In the literature of the subject there is quite an evident division into three stages of development in the concept of marketing: From the concept of transactional marketing, through strategic (competitive) marketing, to partnership marketing (also referred to as the marketing of mutual relationships).

For many years buyer-supplier relationships in the fashion industry have been shortterm and adversarial, characterized by multiple sourcing, price orientation, and competitive bidding (Barnes and Lea-Greenwood 2006; Hines and McGowan 2005).

But as shorter product life cycles and rapidly changing consumer demands have led to a renewed focus on agility as a means of reducing lead times, there has been a predominant shift away from adversarial relationships to strategic partnerships based on commitment, trust, and continuous improvement which enable the development of long-term upgraded supplier capabilities (Hines and McGowan 2005; Bixenden and Abratt 2007).

New theses have been proposed, with the major thesis assuming that many markets' transactions are not perceived by exchanging parties in a statistical, but a dynamic approach, which is from the perspective of contacts of various types. Apart from the economic dimension, they also have an important non-material (social, symbolic, and emotional) level.

Target markets, consumers (households), and suppliers are in particular the key areas of interest of fast fashion retail chains. Therefore, fast fashion retail chains look for ways to create commercial offers that allow for maintenance of existing customers and acquisition of the new ones (Shajahn 2006). Detailed recognition of demands of target segments ought to result in the creation of commercial offers satisfying final customers (Sirdeshmukh et al. 2002). The offer for individual customer may become attractive if suitable sources of purchase are provided. Hence, indication of suppliers as partners, who enable, in practice, the development of a competitive market offer (Chen 2009; Mentzer et al. 2000).

The policy of performing purchase and related problems concerning cooperation is the element of activity of fast fashion retail chains. It is the subject of cooperation between the sphere of trade and is focused on relationships between enterprises and their suppliers. The problems associated with the issues of selection of suppliers have been analyzed. The 
evolution of the purchasing function was discussed by Stannack and Jones (1996). In the case of fast fashion retail chains, the stage of doing shopping directed only on products is already behind in these organizations. Another model was presented by Reck and Long. This model shows four stages of purchasing function (Reck and Long 1988). Cooperation between suppliers and fast fashion retail chains should allow for generation of surplus of income over costs, and this demands cooperation with suppliers (Pilarczyk et al. 2001).

The relationship approach imposes a broader perspective on the strategy of retailers' buying, while indicating not only direct chain suppliers but also their cooperating partners as their recipients.

Including a relationship marketing approach in practices of fast fashion retail chain management is a result of the systems implemented by the company and supplier's activities.

\section{Fast Fashion Supply Chain Management}

Many fashion companies serve customers all over the world and outsource the production of clothes to manufacturers located in developing countries and those where the production costs (labor and materials) are lower (Graafland 2002). Cost-effectiveness has become the major reason why fashion retailers undertake international outsourcing (Di Gregorio et al. 2009); however, other factors, including competition and customer expectations regarding a more diversified product offer and keeping prices of clothes low, should also be mentioned (McMaster et al. 2020).

These determinants have led to the emergence of the phenomenon of "fast fashion", i.e., a fashion offer characterized by significant variability (even up to 12 sub-seasons can be distinguished) of mass-produced clothes, often of poorer quality, whose delivery cycle (from design, through production, transport, to availability at outlets) and life cycle (use by the buyer) have been significantly shortened (Turker and Altuntas 2014).

The idea of fast fashion is often presented in the literature on the subject as a business model that focuses on an efficient supply chain enabling the achievement of product diversity with simultaneous cost effectiveness, in order to meet the changing expectations of the buyers of clothes (McNeil and Moore 2015; Camargo et al. 2020). The main characteristics of the fast fashion business model may include:

- A direct-to-consumer business model with a focus on mass production of clothes;

- A focus on achieving economies of scales, producing large batches of the same garments;

- $\quad$ About 2000 to 11,000 pieces introduced annually;

- Forecast-driven to predict future trends and understand what customers want in the near future;

- A focus on scaling the number of brick-on-mortar stores; e-commerce is important, but not a major income source;

- The goal of providing the products as cheaply as possible, at a fast pace, with a lead time of 2-6 weeks;

- Offshoring production due to cost savings (outsourcing production and a high number of suppliers);

- $\quad$ Reasonable stock, but possible excess stock due to mass production;

- The potential to be perceived as unethical and unsustainable due to outsourcing production to countries where the labor costs are low.

At the same time, due to the acceleration and shortening of the delivery cycle of ready-to-wear clothes from 2-6 weeks to a week or even several days, the term of "ultrafast fashion" has also occurred (Weinswig 2017). Ultra-fast fashion corresponds to the market trends to a greater extent, primarily due to the truly short lead time. It does not always mean clothing sold at an extremely low price, which results from the concept of onshoring (relocating business processes to a lower-cost location inside the national borders) or nearshoring (relocating business processes to the neighboring countries). According to Hendriksz (2017), there are currently five major new retailers that have adopted the 
ultra-fast strategy: ASOS, Boohoo, Missguided, Choosy, and Fashion Nova.

The supply chain in the fashion industry is complex. On the one hand, it consists of market entities, such as material suppliers, manufacturers, logistics operators, fashion retailers, and customers, while on the other hand, of activities including transformation of raw materials and launching finished products onto the market (Moon et al. 2017). Vertical integration of participants and the activities based on appropriate relationships and conducted by them is necessary for the supply chain to function well (Camargo et al. 2020).

Camargo et al. (2020), Ye and Lau (2018) and Lee (2002) prove the existence of various types of supply chains and the strategies implemented in them. The most common ones in the fashion industry include efficient, risk-hedging, responsive, and agile supply chains. Their synthetic description is presented in Table 1.

Table 1. The most popular supply chain strategies in fashion industry.

\begin{tabular}{|c|c|}
\hline Supply Chain Strategy & Characteristics \\
\hline Efficient (lean) supply chain & $\begin{array}{l}\text { Usually aims at achieving economies of scale, } \\
\text { where there is a need for high use of effective } \\
\text { communication throughout the chain. } \\
\text { The information system as an "integrator" } \\
\text { enables production and distribution schedules } \\
\text { to be optimized and creates and maintains } \\
\text { dynamic supplier networks. }\end{array}$ \\
\hline Risk-hedging supply chain & $\begin{array}{l}\text { Aims at sharing resources in order to share } \\
\text { risks in case supply chain disruption happens. } \\
\text { It is an exchange of information among firms } \\
\text { that are sharing inventories and might face } \\
\text { supply chain risks. }\end{array}$ \\
\hline
\end{tabular}
supply chain risks.

Focuses on strategies that allow the company to be responsive and flexible to customers' changing needs.

It can also involve the customer in the design process of product development, creating a Responsive supply chain direct connection between customer choices and the factories that manufacture these products. Finally, agile supply chains seek to be demand-driven and are more likely to be information-based, rather than forecast- and inventory-based, such as most conventional supply chains.

Seek to be demand-driven and are more likely to be information-based, rather than forecast and inventory-based, such as most conventional supply chains.

Agile supply chain A quick response focuses on collaboration and vertical integration in order to enhance supply chain efficiency. A quick-response supply chain is based on the sharing of information, and it is demand-driven based on current and previous sales information.

Source: (Camargo et al. 2020; Ye and Lau 2018; Lee 2002).

Literature studies and observation of the operating practice of integrated supply chains in the fast fashion industry allow us to recognize how different strategies are successfully combined to achieve the best effect. Combining the lean supply chain and agile supply chain forms a hybrid called "leagility", which allows the advantages of each component to be used-flexibility and reactivity to changes in demand, consumer preferences, market trends, etc. (agile approach), while limiting any internal and external variation as much as 
possible (lean attitude) (Camargo et al. 2020; Ye and Lau 2018). However, an alternative strategy to fast fashion is handling multiple products with a fixed-block inventory and a selling cycle that matches customer profiles and supply capabilities. This proposed strategy matches the ultra-fashion approach (Zhang et al. 2017).

\section{Fast Fashion Retail Chains in the Time of COVID-19 Pandemic}

The global Covid-19 pandemic affected all sectors of the global economy to an extent unimaginable in its early stages. Currently, the effects of the pandemic are increasingly more often noticed not only in the health and medical spheres, but also in the political, social, and economic spheres. Social distance, self-isolation, remote work, closure of commercial and service outlets, restrictions on the movement of people or even full lockdown have had impact not only on the functioning of the world economy and integrated supply chains, but also on the level of global demand which significantly decreased, and the consumption patterns of buyers that changed (Fernandes 2020).

The fashion industry is one of the sectors that has been seriously affected by the negative effects of Covid-19. As a result of the first wave of the pandemic, by May 2020, the fashion industry had recorded a 7\% drop in sales, and it was the highest value by product category (Figure 1).

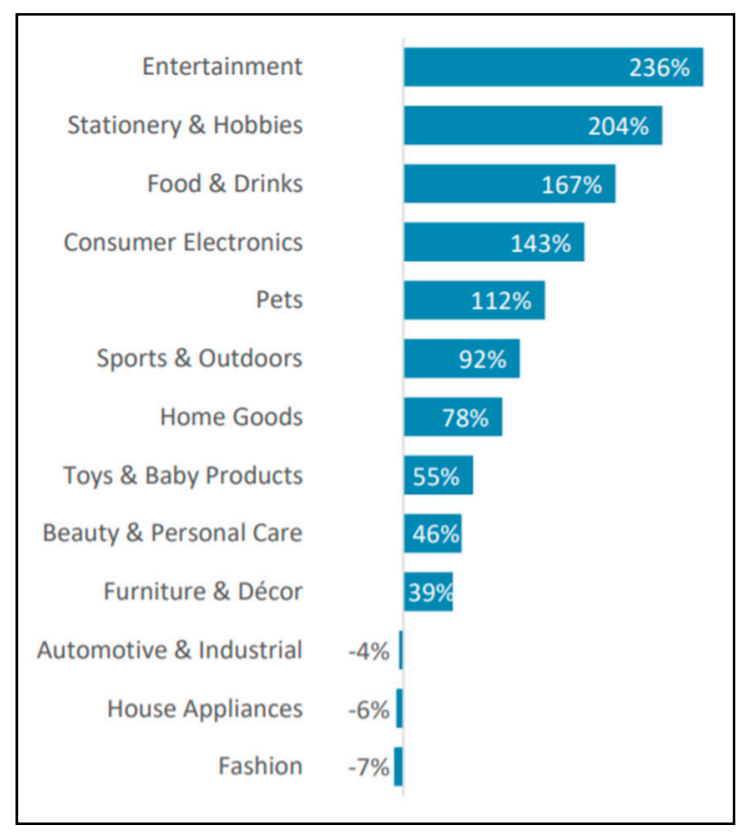

Figure 1. Changes in sales revenue by category in May 2020. Source: (ContactPigeon 2020).

The uncertainty about the future caused by the pandemic revalued social practices in many areas. Staying at home, uncertainty of income, and focusing on personal safety made the need to buy material goods a secondary concern (temporarily). The largest decline in demand by fashion retailers was recorded in March, April, and May 2020. The summary of changes in clothing sales in 2020 in selected countries compared to the same period in 2019 is shown in Table 2. 
Table 2. Retail sales of clothing and accessories monthly (Y/Y \% change) 2020.

\begin{tabular}{cccccc}
\hline & Italy & Germany & Spain & China & USA \\
\hline January & $0.3 \%$ & $0.2 \%$ & $0.9 \%$ & $-34 \%$ & $3 \%$ \\
February & $2.5 \%$ & $0.5 \%$ & $4.6 \%$ & $-36 \%$ & $-51 \%$ \\
March & $-64.5 \%$ & $-51.8 \%$ & $-61.4 \%$ & $-20 \%$ & $-89 \%$ \\
April & $-87.6 \%$ & $-70.90 \%$ & $-90.1 \%$ & $-2.6 \%$ & $-62 \%$ \\
May & $-41.80 \%$ & $-23.6 \%$ & $-66.7 \%$ & $-2.9 \%$ & $-24.3 \%$ \\
June & $-14.7 \%$ & $-16.3 \%$ & $-27.1 \%$ & & \\
\hline
\end{tabular}

Source: (Ricchetti and De Palma 2020).

Consumers' preferences towards clothing category also changed. According to the Sales Intelligence 2020 report (Sales Intelligence 2020), from March 2020, sportswear and clothing belonging to the category of homeware and home office have been the most popular. On the other hand, the pandemic caused the largest decrease in party clothes, such as dresses (by $65 \%$ ) or suits (by $74 \%$ ).

In response to rapid market changes, retailers introduced immediate changes in contracts, and suspended or canceled orders from suppliers around the world, especially from the suppliers in China, Bangladesh, India, Pakistan, Cambodia, Honduras, and Nicaragua.

In the Research Report from October 2020, the Center for Global Workers' Rights states that $65 \%$ of suppliers were forced to accept lower prices of manufactured products, on average by $12 \%$. As a result, $56 \%$ of suppliers to fashion retailers had to accept the terms of sale below the cost (Figure 2).

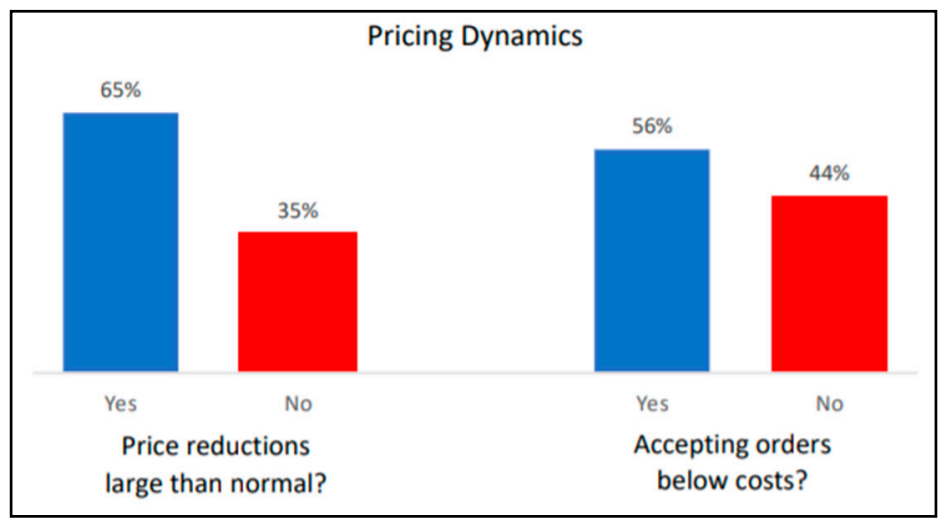

Figure 2. Pricing conditions and pricing dynamics of fashion suppliers due to Covid-19 pandemic. Source: (Center for Global Workers' Rights 2020a).

The terms of payment for the clothes that were ordered, produced, and loaded on ships also changed. Currently, $66 \%$ of fashion retailers have imposed payment terms of 60 days or longer ( 90 or even 120 days). On average, suppliers are paid 77 days after the order is dispatched, while before the pandemic the average payment term was 43 days (Figure 3). 


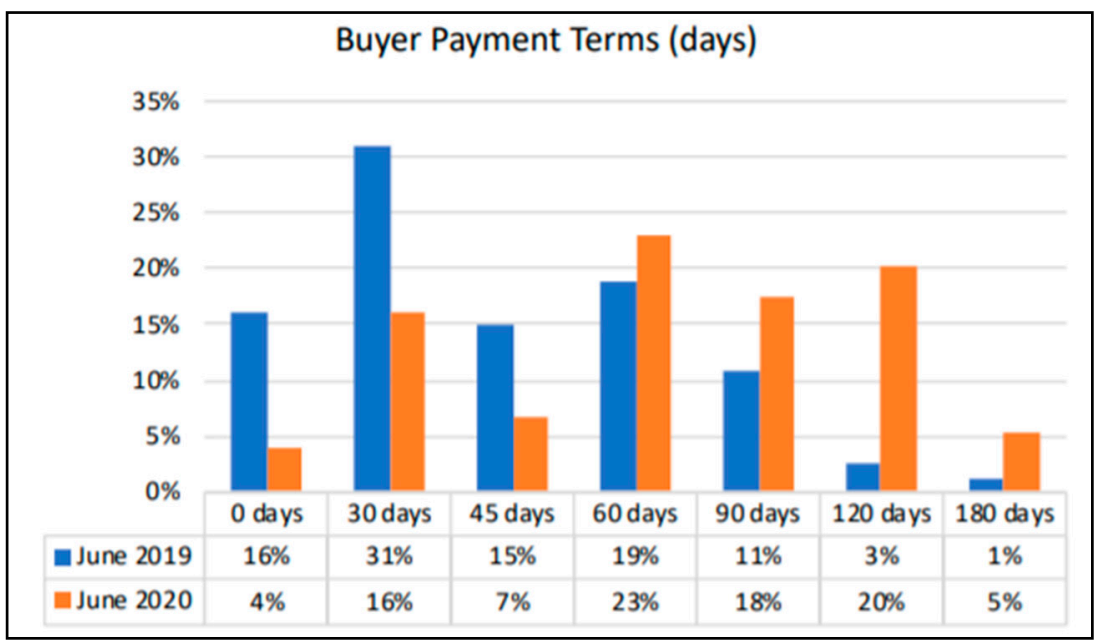

Figure 3. Buyer payment terms (days) due to Covid-19 pandemic. Source: (Center for Global Workers' Rights 2020a).

Another practice which put clothing suppliers in an extremely difficult financial situation or even on the verge of bankruptcy was the cancellation of orders during production, and even of those manufactured and delivered to fashion retailers, despite the fact that they had a contractual obligation to pay for these orders. According to data from the Center for Global Workers' Rights (CGWR), $80 \%$ of suppliers integrated in fast fashion supply chains experienced the effects of cancellation of orders by fast fashion retailers (Figure 4).

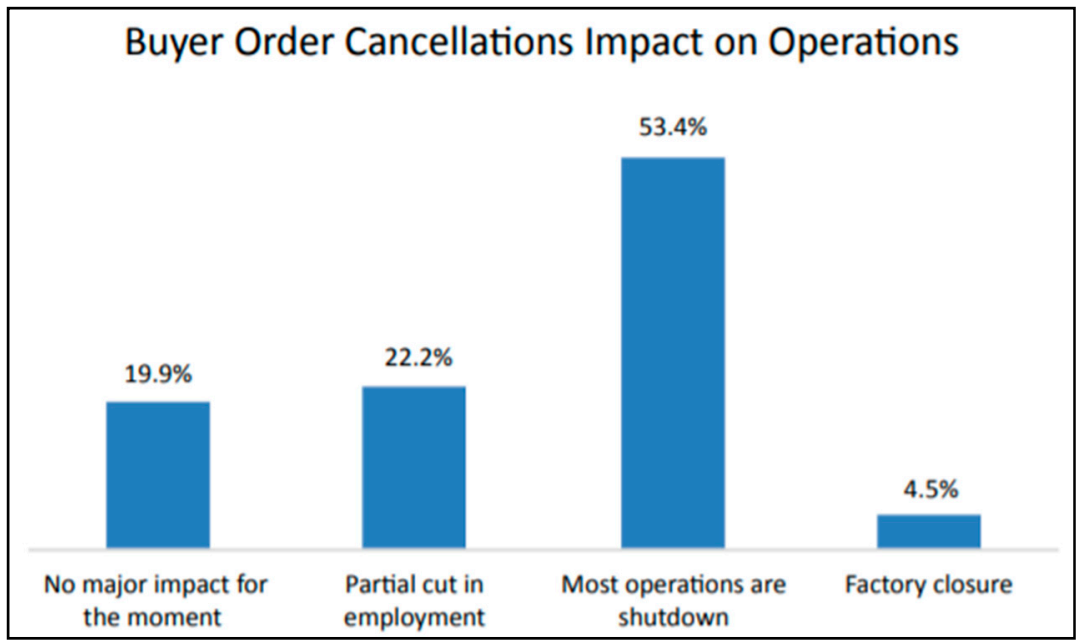

Figure 4. The effects of fashion retailers' order cancellation on suppliers' operations due to Covid-19 pandemic. Source: (Center for Global Workers' Rights 2020b).

The industry analyses of the Center for Global Workers' Rights (2020b); Donaldson (2020) show that when canceling contracts, fashion retailers most often did not feel obliged to cover suppliers' losses caused by their decisions, including the costs of materials purchased in advance, or incurred production costs (Figure 5). As a consequence, every fifth supplier dismissed employees without being able to pay them the due remuneration (or paying only its small part), every second significantly limited production activity, while about $4.5 \%$ of suppliers went bankrupt. 


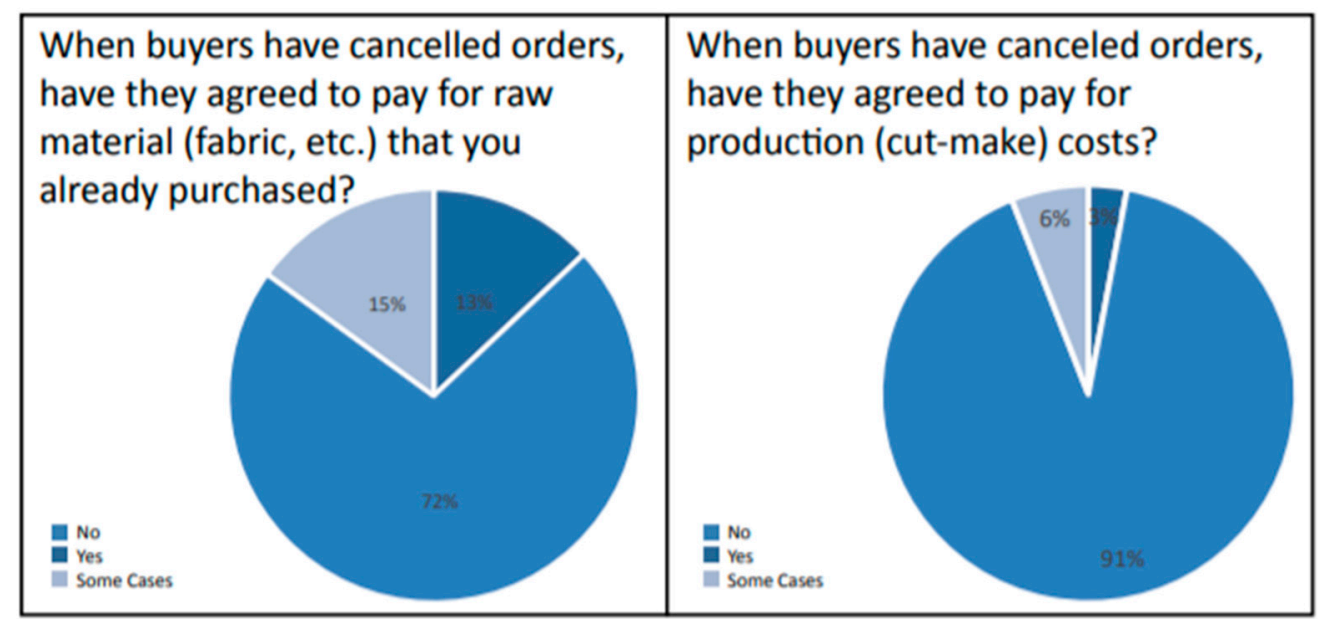

Figure 5. To what extent fashion retailers agreed to pay for raw material and cut and make production costs. Source: (Center for Global Workers' Rights 2020b).

It is interesting that when canceling orders, many fast fashion retailers referred to the force majeure clause in their contracts (also called superior force or acts of God), which addresses the circumstances in which a party may be excused from the full performance of a contract under the principle of force majeure. This clause allows a party to a contract to fail to comply with its contractual obligations if circumstances that are unforeseen or through no fault of the party have occurred (Dinar and Budiartha 2020). The purpose of the force majeure clause is to allocate the risk for both the parties to the contract and indicate those events that will effectively suspend the liability, also financial, of the party or parties. The International Chamber of Commerce (International Chamber of Commerce 2020) in Paris proposed a Model of Force Majeure Clause, which includes the notion of "plague [or] epidemic" among presumed force majeure events, but not "pandemic". The wording may be important in some jurisdictions. However, even if the "pandemic" was considered a force majeure event, the arbitral tribunal would not necessarily accept the claim of withdrawing from the contract without paying the due amount (in whole or in part), especially because the pandemic situation, lockdown, and other situations apply only to brick-and-mortar stores, while retailers can still sell online, and the stores will reopen. Force majeure may justify a delay in payment, but not cancellation of the order. Moreover, such practice is inconsistent with the due diligence requirements under the United Nations Guiding Principles on Business and Human Rights (UNIGPs) and the OECD guidelines (Worker Rights Consortium 2020).

The described practices of using force majeure to improve business efficiency and financial liquidity indicators are not only unethical. They show a lack of concern for some fast fashion retailers about the situation of suppliers, their employees, and families, who as a result of legal action lose income or jobs when factories are closed. They will be replaced by other suppliers who will be exposed to similar treatment. It should be noted that the problem goes deeper and proves the existence of power imbalances and asymmetry in fast fashion supply chains.

However, it should be stated that not all companies in the fashion industry showed such low sensitivity and lack of social responsibility. The Worker Right Consortium (WRC), together with the Center for Global Workers' Right (CGWR), launched the "Covid-19 Tracker" campaign, which identifies positive and negative business practices. As a result, 2 lists of companies were created (they are regularly updated, as of March 2020). They include those which operate ethically and have committed to fully pay for orders in progress and completed by suppliers, as well as those that avoid liability. The list of retailers according to Covid-19 Tracker is presented in Table 3. 
Table 3. Covid-19 Trackers: Brands which are acting responsibly toward suppliers and workers (updated 14 January 2021).

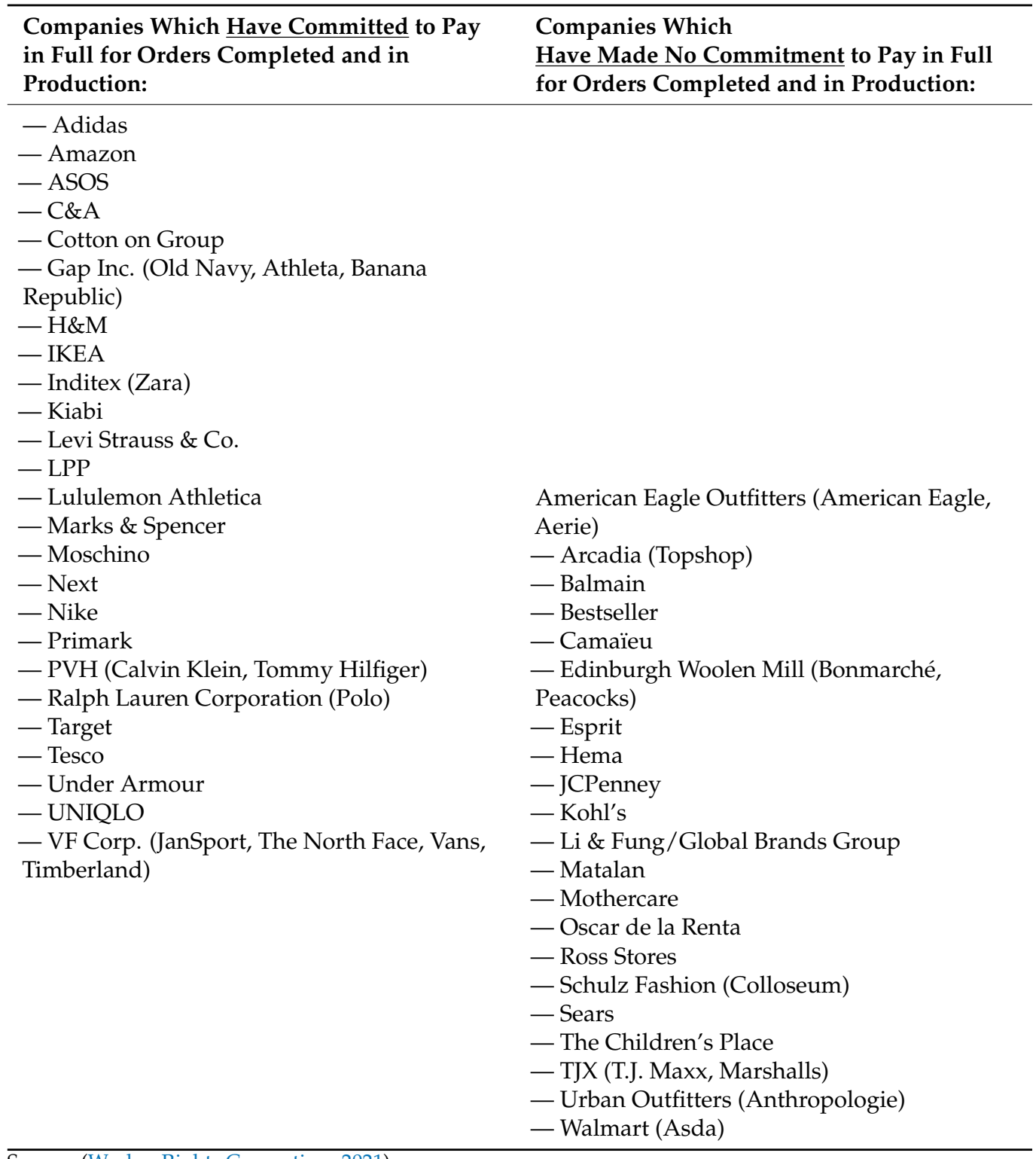

Source: (Worker Rights Consortium 2021).

The companies that were classified as socially responsible towards their suppliers and their employees met the following criteria (Worker Rights Consortium 2021):

a. They pay a pre-agreed price for goods in the production process, manufactured and shipped in accordance with the order, without requesting price discounts and rebates;

b. They do not cancel orders made with suppliers, and if they do so, then for full compensation of costs incurred by suppliers;

c. They do not postpone the agreed delivery times for delayed payments, and if they do, the delays are small and the extended waiting time for payments is compensated for suppliers;

d. If there are delays in payments to suppliers, commercial companies facilitate suppliers' access to cheap sources of financing of their operation so as not to disturb the financial liquidity of suppliers.

It should be indicated that the companies are liable to their suppliers' changes. The first rankings from March 2020 clearly indicated that many retailers from the fashion industry 
(and not only) changed the terms of the contract and did not meet their contractual obligations, while the list of socially responsible companies was short. However, the activities of such organizations as the Worker Rights Consortium or the Center for Global Workers' Rights, popularizing good business practices and stigmatizing unethical behavior, influenced public opinion, and contributed to changing the operating model of many fast fashion retailers.

The attitudes of consumers have become a determinant of great importance (if not the most important). According to the Edelman Trust Barometer 2020 (Edelman Trust Barometr 2020), 65\% of consumers believe that the reaction of the brand during the crisis will have a huge impact on the likelihood of its purchase in the future, and $29 \%$ of buyers started using a new brand due to its actions towards stakeholders during the pandemic. It is the purchasing behavior of consumers and their market decisions that translate into the financial results of fast fashion retailers.

\section{Research Methods}

Based on the theoretic deliberation of retail chains' relationships with suppliers in the pandemic times, qualitative research was conducted to supplement the theoretical background. The purpose of this study was to identify how fast fashion retailers maintain relationships with their suppliers in supply chains. The conducted research enabled us to reveal answers to the following research questions:

1. What are the good practices of fast fashion retailers in terms of relationships with suppliers?

2. Can socially responsible, trustworthy fast fashion retailers stay profitable in the Covid-19 pandemic?

Yin (1993), followed by Tellis (1997), identified three types of case studies: Exploratory, explanatory, and descriptive. Stake (1995) included two others: Intrinsic-when the researcher has an interest in the case; instrumental — when the case is used to understand more than what is obvious to the observer (Stake 1995). The conducted research was descriptive in nature, conducted in order to describe a particular phenomenon within its context, and was not intended to provide conclusive evidence, but to have a better understanding of the problem (Henson and Roberts 2006). A descriptive intrinsic case study was the method applied in the research.

According to Meyer (2001), case studies are tailor-made to explore new processes or behaviors, or ones that are little understood. Fast fashion retailers' behavior in the pandemic time is a definitely new phenomenon, taking into consideration the time scope and scale of Covid-19 crisis, as well as problems it created. In addition, our understanding of reasons behind fast fashion relationships with suppliers is scarce. Taking the abovementioned arguments into consideration, a case study method may be applied in the research process.

A case study is a research approach that is used to generate an in-depth, multi-faceted understanding of a complex issue, event, or phenomenon in depth and in its natural context (Crowe et al. 2011). With the case study method, a critical decision is the selection of cases. Contrary to the sampling approaches typically adopted in quantitative research (e.g., random, stratified, or statistical sampling), cases are selected because they are particularly suitable for illuminating a phenomenon and for extending relationships and logic among variables. Researchers have to decide about the number of studied cases.

Case studies may be applied as a single case study, which uses a particular case, or a multiple (collective) case study, which involves studying multiple cases simultaneously or sequentially to generate a broader appreciation of a particular issue (Crowe et al. 2011).

The research in question applied a single case study. According to Ozcan et al. (2017), single cases allow researchers to study a complex process over an exceptionally long period that would not be practical through multiple cases.

Corresponding to Yin (2014) rationales for conducting single case research, it may be stated that single case study is suitable for:

1. Studies that examine a particular phenomenon; 
2. Studies that focus on questions examining "how and why things emerge, develop, grow, or terminate over time";

3. Cases are studied in detail from multiple perspectives and data sources;

4. Data sources are diverse and rich.

The conducted research covered all the areas mentioned above, meeting the requirements of single case studies.

Crowe et al. (2011) followed by Rashid et al. (2019) identified several stages of research activity when planning and undertaking a case study, i.e.:

1. Defining the case;

2. Selecting the case;

3. Collecting, analyzing, and interpreting the data;

4. Reporting the findings.

The same stages were implemented in the conducted research. The first stage (defining the case) consisted of formulating the research questions, clarifying the nature and time period covered by the case study (i.e., its scope, beginning and end), the relevant market sector, and the types of evidence to be collected. It was assumed that the fast fashion industry would be the subject of interest, as this market sector had to face serious challenges caused by the Covid-19 pandemic. The temporal scope of the research covers activity of Inditex undertaken between February and November 2020 (i.e., the three quarters of 2020). The period was chosen decisively due sudden and unexpected change in global business environment, caused by the pandemic. It might have caused a moral hazard to treat weaker partners unfair by retail fast fashion chains.

Data in the case study method were collected by multiple means that consisted of potential qualitative or quantitative information retrieved from primary and/or secondary sources. Case study data often provide advantages in being able to integrate both objective and perceptual data (De Masis and Kotlar 2014). The conducted research was based on both primary sources (in the form of non-participant observations of business practices) and secondary sources (documents available online).

The next stage was to select the case. The sampling of a single case was straightforward. A single case was chosen because it was unusually revelatory and extreme exemplars and because it offered opportunities for unusual research access (De Masis and Kotlar 2014).

The subject of the research was Inditex. The company was chosen purposefully, as it is one of the world's largest fashion retailers, selling in 202 markets through its online platform or its over 7000 stores in 96 markets. The company collaborates with suppliers across 44 different markets to source most of the apparel products. Inditex, representing the fast fashion industry, is one of business suffering from Covid-19 pandemic (Inditex Official Website 2021).

In order to develop a thorough understanding of the case, the third stage of a case study research was proceeded. Data were collected from multiple sources, organized, analyzed, and coded to allow the key issues, both derived from the literature and emerging from the dataset, to be easily retrieved at a later stage. Attention was paid to the relationship between different causes, effects, and outcomes.

As the last stage of the case study research, the findings were reported, and conclusions drawn.

\section{Research Findings}

\subsection{The Company's Background}

Inditex (Industria del Diseño Textil S.A.) is a fast fashion retailer whose main activity is the distribution of fashion articles, including clothing, footwear, accessories, and household textile products. Eight brands operate within the company now, i.e., Zara, Pull \& Bear, Massimo Dutti, Bershka, Stradivarius, Oysho, Zara Home, and Uterqüe. Among them, Zara is the largest, the most famous, and one of the first brands introduced to the market (its history dates back to 1975). 
Following the brand's success on the domestic market, the company began its international expansion at the end of the 1980s by implementing a strategy of market development, and then a product development strategy and diversification strategy (simultaneous market and product development). In 1991, the sophisticated Massimo Dutti brand appeared in the company's offer, which was originally targeted at men, and since 1995 also at women. Pull \& Bear, which joined the Inditex group in 1991, is another brand in the company's portfolio. It is a brand targeted at young consumers, just like Bershka (established in 1998) and Stradivarius (launched in 1999). In 2001, Inditex supplemented the product offer with underwear under the Oysho brand, and in 2008 with exclusive accessories sold under the Uterqüe brand (Inditex Official Website 2021).

Currently, the company is a leader in the global fast fashion market (Orcao and Perez 2014), which is proven among others by the number of countries where the company offers its products. As the data from Inditex show (Inditex 2021), the researched fashion retailer has 7199 physical stores in 96 countries, and through the online platform it reaches consumers in 202 countries. The number of stores globally by brand is presented in Table 4 .

Table 4. Number of stores globally (divided by brands).

\begin{tabular}{cc}
\hline Inditex's Brand & No of Stores \\
\hline Zara & 2208 \\
Pull \& Bear & 920 \\
Massimo Dutti & 715 \\
Bershka & 1060 \\
Stradivarius & 978 \\
Oysho & 654 \\
Zara Home & 575 \\
Uterqüe & 89 \\
Total: & 7199 \\
\hline
\end{tabular}

Source: (Inditex Official Website 2021).

All shops receive goods twice a week, which is more often than competitors. Each delivery includes new items adapted to local demand in terms of sizes, models, seasons, and other requirements. Maintaining short lead times and short transportation times, requires proper integration within the supply chains and good management of manufacturing, trading, and logistics processes (Aftab et al. 2018). According to the company's data, Inditex cooperates with 1985 suppliers and 8155 factories worldwide, which makes Inditex one of the world's biggest recipients of fashion goods (Inditex Official Website 2021).

\subsection{Inditex Supply Chain Model}

Inditex targets a general industry-wide mass market rather than a luxurious segment in the industry and puts emphasis on providing products that contain the latest and most trendy fashionable design concepts with reasonable physical quality, rapidly, and at attractive prices. Such products are categorized as fast fashion products, which means that new styles can emerge suddenly, its demand surging in popularity and then quickly fading away. This makes demand for fashion apparel product to be highly unpredictable and thus suggesting lower forecast accuracy (Aftab et al. 2018).

The retail giant capitalizes on this problem by rapid responsiveness to the emerging new styles. About $20 \%$ of the company's total production is premade, while $80 \%$ is produced according to the market response. Inditex can bring a new product from conceptdesign-production-store shelves in 3 weeks, which makes the company able to offer customers fresh assortments of product lines according to the market demand (Inditex Annual Report 2019).

Inditex's success is based on vertical integration. Working with a minimum inventory across its supply chain, the firm's strategy is based on a well-established IT infrastructure, which provides accurate data to its supply chain (Zhang et al. 2017). The model of the supply chain of Inditex is presented in Figure 6. 


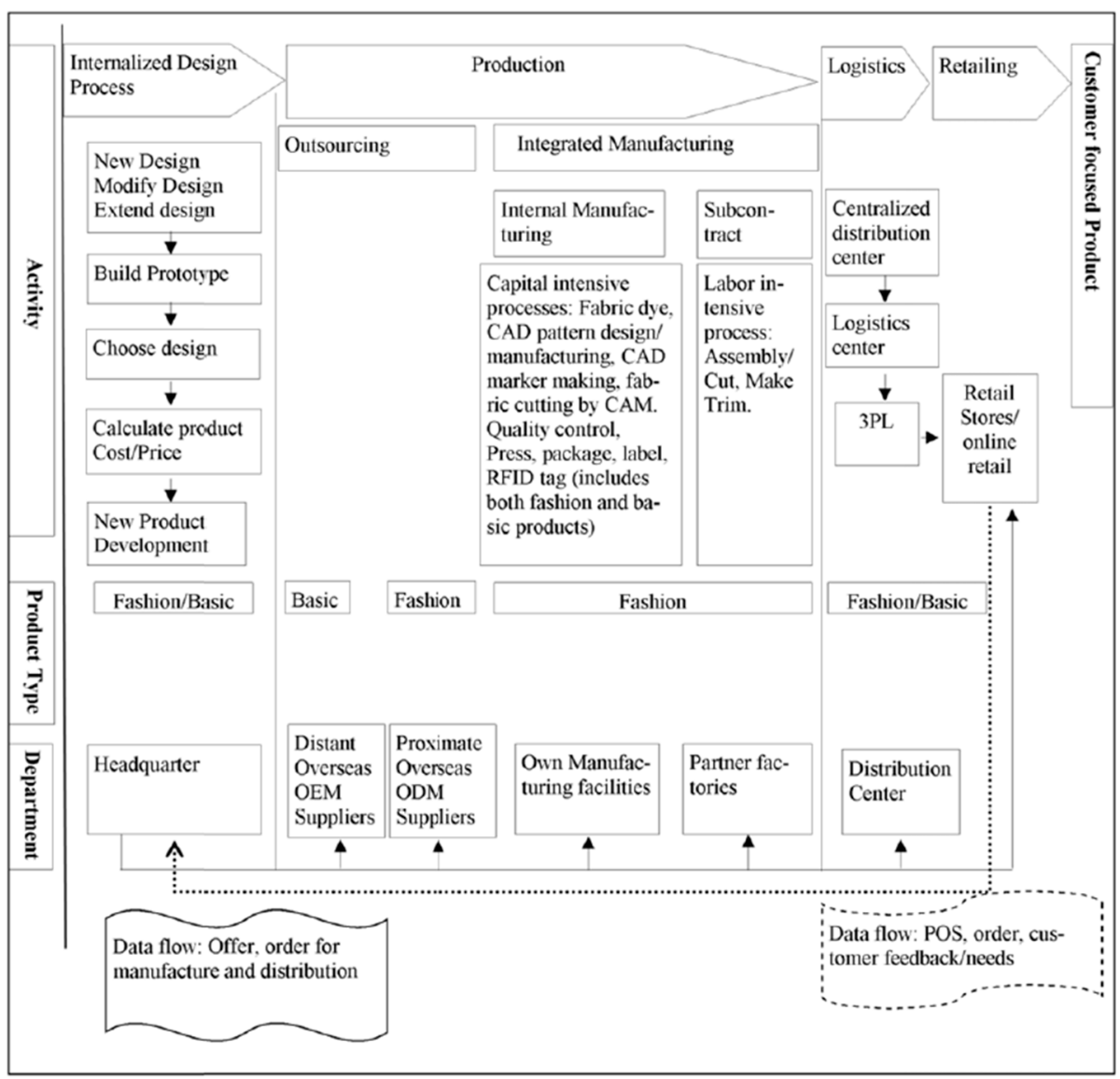

Figure 6. A framework illustrating Inditex's integrated operations and product-information flow across the supply chain. Source: (Aftab et al. 2018).

The process starts in the product development department, which is provided with qualitative and quantitative (POS) data collected from retail stores. These data are then turned into a constant stream of fresh and customer-oriented designs of products. The design phase is fully standardized, which allows product adaptation into different colors and styles in short lead time after precise customer order specification has been sent to suppliers.

Inditex strategically customizes its sourcing strategy according to requirements of product types. To attain rapid responsiveness to demand changes in terms of volume, variety, and frequent product replenishment (according to the fast fashion concept), Inditex performs the capital-intensive manufacturing process in-house and outsources laborintensive assembly process to subcontractors in five continents organized as sourcing networks. Efficiency is achieved due to economies of scale, simplified communication, and coordination of production in the sourcing networks (Aftab et al. 2018; Inditex Annual Report 2019; Orcao and Perez 2014).

Inditex also owns a network of automated distribution centers (cross-docking centers), where products, regardless of their origin or destination are delivered for sorting, packing, and freight loading to the company's logistic centers and farther to the global network of stores. To maximize the delivery speed, and maintain short lead time, Inditex uses premium transportation modes for inbound/outbound transport, mainly air shipment of floor ready merchandise (i.e., pre-tagged, pre-ticketed, and pre-occupied with all the necessary details and information such as their specifications for style, size, type, color, and price; this information is required in the retail store and is done before it reaches the point of sales) (Aftab et al. 2018).

Inditex is forward integrated due to the ownership of retail stores. It allows for control over inventories in terms of product types, quantity offered, pricing, and other factors. 
Retail ownership enables unified data collection and communication via IT systems, such as RFID, to track real-time information on global sales, customer demand and preferences, and inventory status at the precise stock-keeping unit in each store. These data can be quickly transferred to the upstream operations of design, procurement, production, and distribution in a cost-effective way.

Inditex's integrated supply chain strategy has enabled the development of quick response capability which reduces inventory variations, order-to-delivery lead time, ensuring lean inventory and a high level of supply chain responsiveness to adapt products to the latest fashion trends and customer feedback. Inditex can successfully counter the negative effects of short product life cycles, high product variety, demand uncertainty, and is thus able to closely match product supply to the stores with market demand. The supply chain may be characterized as highly (super) responsive, based on good relationships with their suppliers (Aftab et al. 2018; Camargo et al. 2020).

\subsection{Relationships of Inditex with Suppliers in COVID-19 Pandemic}

Inditex declares that its priority is people: They protect workers' human rights across all the suppliers and manufacturers making the garments. The sustainable business model allows suppliers and manufacturers to develop their businesses, which grow in parallel with the company, and generate a positive economic impact in many countries (Inditex Official Website 2021).

All the suppliers and manufacturers must comply with the stringent requirements stipulated in a Code of Conduct for Manufacturers and Suppliers. The code outlines exacting standards for responsible management, which prioritize the protection of human rights and the promotion of international labor conventions. The document presents 13 rules to be followed (Inditex Official Website 2021), i.e.,

1. No forced labor;

2. No child labor;

3. No discrimination;

4. Respect for freedom of association and collective bargaining;

5. No harsh or inhumane treatment;

6. Safe and hygienic working conditions;

7. Wages are paid;

8. Working hours are not excessive;

9. Regular employment;

10. Traceability of production;

11. Health and safety of products;

12. Environmental awareness;

13. Confidentiality of information.

All Inditex's operations shall be developed under an ethical and responsible perspective. All persons, individuals, or entities, who maintain, directly or indirectly, any kind of employment, economic, social and/or industrial relationship with Inditex, shall be treated fairly and with dignity. All Inditex's activities should be carried out in a manner that most respects the environment. All manufacturers and suppliers (production centers that are not the property of Inditex) should fully adhere to the commitments and ensure that the standards which are set forth in the code are met (Inditex 2021).

The code was introduced in 2000, and the rules have been put into practice since then, even in the Covid-19 pandemic times. In August 2020, Inditex pledged to maintain workers' rights throughout its supply chains and the stability of payments to suppliers. The pandemic and associated lockdowns have negatively influenced the fast fashion industry, making many companies struggle to survive due to the COVID-19 crisis, with many retailers canceling orders as they closed stores around the world, leading to the shuttering of thousands of factories and huge job losses.

Inditex reiterated a commitment to ensuring health and safety standards were met and collective bargaining rights and workers' rights to unionize maintained throughout 
its supply chains. It has also committed to stable payment terms in a way that allows suppliers to honor payments to workers (Dowset 2020).

Based on Inditex's response to the Covid-19 Tracker survey, it may be noticed that the company did not change its relationships with suppliers in their supply chain. Inditex pays for goods received to their warehouses in maximum 90 days. After an order is placed, the company does not change orders (volume, specs, deadline, etc.) and does not ask suppliers for any discounts or price reductions. Contracts signed with the suppliers have no clauses for financial penalties for contract non-compliance, such as late delivery, wrong specification, etc.

Inditex has committed in full to all completed and in-production orders in the period since the Covid-19 outbreak. When needed, the company supports suppliers with access to local finance with a letter of credit or other means. The main aim of this activity is to ensure all wages are paid, especially during periods of lockdown. Inditex's sustainability teams cooperate with suppliers and manufacturers in the respective cluster payment of wages and other benefits required by law.

Another subject of interest is to make sure factories are safe places to work, workers keep social distancing, sanitizing practices are implemented, and workers are provided with adequate protective equipment to be protected from infection.

In collaboration with the IndutriALL Global Union, the International Labour Organisation, Ethical Trading Initiative, the International Trade Union Federation, ACT (Action, Collaboration, Transformation), and other retailers, Inditex has been working on a strategy to minimize the impact of Covid-19 on the economy, to protect garment workers' income, health, and employment, and to support employers to survive during the Covid-19 crisis, especially in countries with weak health and social protection systems (International Labour Organization 2020).

The first quarter of 2020 was a difficult time for Inditex, especially compared with the similar period of 2019. In the third quarter of 2020, Inditex shows a strong recovery in operations: Store sales improved progressively, online sales grew $76 \%$, sales reached $€ 6.1$ billion, EBITDA $€ 1.8$ billion, and net income reached $€ 866$ million (see Figure 7).

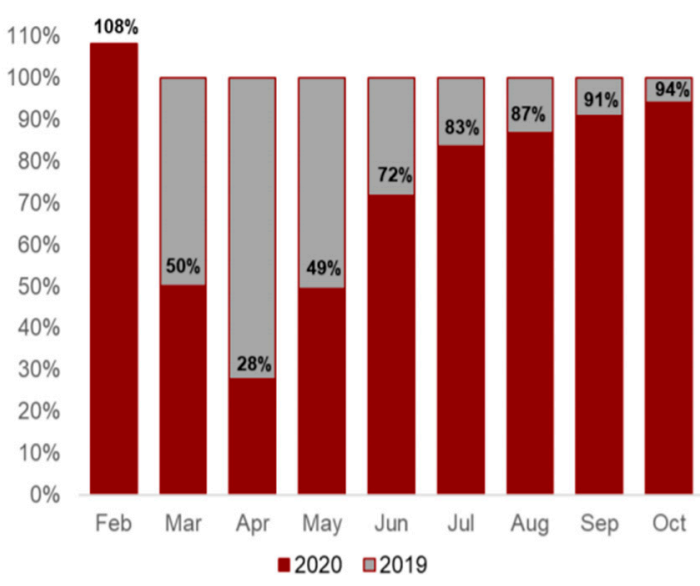

Figure 7. Store sales of Inditex (February to October 2020 compared to the same period in 2019). Source: (Inditex 2020).

Taking online sales into consideration, the company reported a strong online progression: $75 \%$ increase in online sales in constant currency and $44 \%$ increase in online visits (to 3.4 bn) (Inditex 2020).

During the period considered, the company's operating expenses decreased by $10 \%$ in the quarter, inventory was $11 \%$ lower, and cash position increased $7 \%$, to $€ 8.3$ billion, reaching a historic high. The financial data for Inditex's third quarter of 2020 show significant improvement in operations. The results have been materially affected by the health crisis, with temporary store closures and restrictions to operations. To minimize the impact, 
the researched company has actively managed the supply chain, inventory, and operating expenses in the period (Inditex 2020).

\section{Discussion}

On the grounds of literature studies, as well as collected information, we can state that close and ethical cooperation with suppliers, based on socially responsible relationships, has become a more and more important part of strategy for commercial chains. The crisis situation caused by the global Covid-19 pandemic has created (and still creates) a moral hazard to treat weaker partners unfairly by retail fast fashion chains, which was noted by the Worker Rights Consortium (Worker Rights Consortium 2021) and Edelman Trust Barometer 2020. There are companies that use any legal measures not to fulfil their obligations as contractors and avoid paying for orders completed and in production. These practices are unethical and harmful towards suppliers, but may also negatively influence the fast fashion retailers, which are perceived as untrustworthy or even greedy by customers, their main stakeholders in terms of relationship marketing.

The descriptive case study research allowed us to observe, analyze, and report good practices of fast fashion retailers in terms of relationships with their suppliers based on the Inditex example. First, it must be noticed that the company does not take the advantage of having a more powerful position in the supply chain. Second, the researched company supports its suppliers by paying in full for goods received to their warehouses in a maximum of 90 days, or not canceling orders or not referring to the force majeure clause in their contracts, which addresses the circumstances in which a party may be excused from the full performance of a contract due to a pandemic situation. After an order is placed, the company does not change orders (volume, specs, or deadline, etc.) and does not ask suppliers for any discounts or price reductions. Contracts signed with the suppliers have no clauses for financial penalties for contract non-compliance, such as late delivery, wrong specification, etc.

Inditex also introduced and required the implementation of a Code of Conduct for Manufacturers and Suppliers even (or especially) in the crisis situation of the global pandemic. The code outlines exacting standards for responsible management, which prioritize the protection of human rights and the promotion of international labor conventions.

The researched company reiterated a commitment to ensuring health and safety standards were met and collective bargaining rights and workers' rights to unionize maintained throughout its supply chains. It has also committed to stable payments to workers.

The observed, identified, and analyzed activities may be described as good practices of fast fashion retailers in terms of relationships with suppliers, maintained in the Covid-19 pandemic. They therefore provide answers to the first research question.

The response to the second research question as to whether socially responsible, trustworthy fast fashion retailers can stay profitable in the Covid-19 pandemic required financial data analysis. Based on information provided in the Interim Nine Months 2020 Results, it may be noticed that in the first months of the pandemic (March, April, and May 2020), the store sales of Inditex dropped down dramatically (respectively to 50\%, 28\%, and $49 \%$ of the sales level in March, April, and May 2019). In the following months, a growing trend was observed in store sales. Another important observation was a strong online increase (by 75\%). During the period considered, the company noticed significant improvement in operations. The presented data are clear evidence that strong, positive, and ethical relationships with suppliers have no negative impact on a retailer's financial performance but make the company a trustworthy business partner for all the stakeholders. This finding is coherent with other research results provided by Perry and Wood (2018), Bruce and Daly (2011), and Vereecke and Muylle (2006). 


\section{Conclusions}

In conclusion, it may be noticed that relationships play a pivotal role in contemporary business. Ethical and socially responsible behavior may lead to significant business performance improvements and building supplier partnerships is an important influencing condition of successful fast fashion supply chain management. The conducted research in the form of the descriptive case study method allowed us to answer the research questions. Many factors associated with successful and profitable supplier-retailer relationships have been identified through practice-based approaches. Based on the Inditex example, a series of good business practices were identified, and it was noticed that staying ethical and trustworthy in pandemic times may lead to positive financial results, providing mutual benefits for suppliers and fast fashion retail chains.

This study may enrich our understanding that ethical performance may result in financial success, especially in turbulent times of global crisis, such as those caused by Covid-19 pandemic. It may be concluded that the global crisis will be over, but strong relationships will remain. This notice reflects the idea of the relationship paradigm in management (Äyväri and Möller 2008; Vereecke and Muylle 2006). This study provides tentative evidence for benefits, which derive from business relationships.

On a managerial level, the current study provides useful actionable guidance to managers on how to create and maintain successful relationships between suppliers and fast fashion retailers based on ethical rules.

The study findings have several limitations. A lack of quantitative evaluation prevents generalizability beyond theory. The research subject, Inditex, was selected purposively as it represents the global retailer, and does not represent the situation of other fast fashion retailers operating in the Covid-19 pandemic. In addition, a continuation of research to after-pandemic times may be required. This leaves space for a future study.

Author Contributions: Conceptualization, A.D.-O. and K.B.-R.; methodology, A.D.-O.; validation, K.B.-R.; formal analysis, A.D.-O. and K.B.-R.; investigation, A.D.-O. and K.B.-R.; resources, A.D.-O. and K.B.-R.; data curation, A.D.-O.; writing-original draft preparation, A.D.-O. and K.B.-R.; writingreview and editing, K.B.-R.; visualization, A.D.-O.; supervision, K.B.-R.; project administration, A.D.-O. and K.B.-R.; funding acquisition, A.D.-O. and K.B.-R. All authors contributed equally to the development of the present paper. For the proper paper development, all the phases have been discussed and worked by the authors. All authors have read and agreed to the published version of the manuscript.

Funding: This research received no external funding.

Data Availability Statement: The authors hereby state that all the data provided in the paper can be found in the sources cited and referred to (see references).

Conflicts of Interest: The authors declare no conflict of interest.

\section{References}

Aftab, Afzaful Quin Youanjin, Nadia Kabir, and Zapan Barua. 2018. Super Responsive Supply Chain: The Case of Spanish Fast Fashion Retailer Inditex-Zara. International Journal of Business and Management 13: 212-27. [CrossRef]

Äyväri, Anne, and Kristian Möller. 2008. Understanding Relational and Network Capabilities-A Critical Review. Paper presented at 24th IMP Conference, Uppsala, Sweden, September 4-6. Available online: www.impgroup.org (accessed on 15 January 2021).

Barnes, Liz, and Gaynor Lea-Greenwood. 2006. Fast fashioning the supply chain: Shaping the research agenda. Journal of Fashion Marketing and Management 10: 259-71. [CrossRef]

Bensaou, Ben M. 1992. Portfolios of Buyer-Suppliers Relationships. Upper Saddle River: Prentes-Hall, p. 459.

Bixenden, Michael, and Russel Abratt. 2007. Corporate identity, ethics, and reputation in supplier-buyer relationships. Journal of Business Ethics 76: 69-82. [CrossRef]

Bruce, Margaret, and Lucy Daly. 2011. Adding value: Challenges for UK apparel supply chain management-A review. Production, Planning and Control 22: 210-20. [CrossRef]

Camargo, Lucas Ramos, Susana Carla Farias Pereira, and Marcia Regina Santiago Scarpin. 2020. Fast and ultra-fast fashion supply chain management: An exploratory research. International Journal of Retail E Distribution Management 48: 537-53. 
Center for Global Workers' Rights. 2020a. Research Report: Abandoned? The Impact of Covid-19 on Workers and Businesses at the Bottom of Global Garment Supply Chain. March 2020. Available online: https:/ / www.workersrights.org/wp-content/uploads / 2020/03 / Abandoned-Penn-State-WRC-Report-March-27-2020.pdf (accessed on 8 January 2021).

Center for Global Workers' Rights. 2020b. Research Report: Leveraging Desperation: Apparel Brands' Purchasing Practices during Covid-19. October 2020. Available online: https://www.workersrights.org/wp-content/uploads/2020/10/LeveragingDesperation.pdf (accessed on 8 January 2021).

Chen, Ching Liang. 2009. Strategic thinking leading to private Brand strategy that caters for customers' shopping preferences in retail marketing. African Journal of Business Management 3: 741-52.

ContactPigeon. 2020. Ecommerce Trends during COVID-19. Available online: https://www.contactpigeon.com/cp/resources/ ebooks / ecommerce-trends-covid19.pdf (accessed on 7 January 2021).

Crowe, Sarah, Kathrin Cresswell, Ann Robertson, Guro Huby, Anthony Avery, and Aziz Sheikh. 2011. The case study approach. BMC Medical Research Methodology 11: 100. [CrossRef]

De Masis, Alfredo, and Jossip Kotlar. 2014. The case study method in family business research: Guidelines for qualitative scholarship. Journal of Family Business Strategy 5: 15-29. [CrossRef]

De Wulf, Kristof, Gaby Odekeren-Schroeder, and Dawn Iacobucci. 2001. Investments in Consumer Relationships: A Cross-Country and Cross-Industry Exploration. Journal of Marketing 65: 33-50. [CrossRef]

Dewalska-Opitek, Anna, and Katarzyna Bilińska-Reformat. 2016. Employer Branding as a Development Determinant of Retail Chains in Poland. Management Issues 14: 152-65. [CrossRef]

Di Gregorio, Dante, Martina Muusten, and Douglas E. Thomas. 2009. Offshore outsourcing as a source of international competitiveness for SMEs. Journal of International Business Studies 40: 969-88. [CrossRef]

Dibb, Sally, Lyndon Simkin, William Pride, and O. C. Ferrell. 2003. Marketing. Boston: Houghton-Miffin.

Dinar, I Gusti Agung Ayu Gita Pritayanti, and I Nyoman Putu Budiartha. 2020. A Comprehensive Force Majeure Model Clause in Corporate Transactions in Indonesia. Sociological Jurisprudence Journal 3: 138-44. [CrossRef]

Donaldson, Tara. 2020. Fashion Retailers Cancel Nearly \$1.5 Billion in Orders from Bangladesh. Sourcing Journal. Available online: https: / / sourcingjournal.com/topics/sourcing/coronavirus-bangladesh-garment-factories-retailers-cancel-1-5-billionorders-201652/ (accessed on 18 January 2021).

Dowset, Sonya. 2020. Zara Owner Inditex Pledges Support to Fashion Supply Chain as Coronavirus Bites. Reuters. August 5. Available online: https://www.reuters.com/article/us-inditex-workers/zara-owner-inditex-pledges-support-for-fashionsupply-chain-as-coronavirus-bites-idUSKCN2511MZ (accessed on 18 January 2021).

Edelman Trust Barometr. 2020. Special Report: Brand Trust and the Coronavirus Pandemic. Available online: https: / / www.edelman.com/sites/g/files/aatuss191/files/2020-03/2020\%20Edelman\%20Trust\%20Barometer\%20Brands\%20 and\%20the\%20Coronavirus.pdf (accessed on 15 January 2021).

Orcao, Ana Isabel Escalona, and David Ramos Perez. 2014. Global production chains in the fast fashion sector, transports, and logistics: The case of the Spanish retailer Inditex. Investigaciones Geograficas 85: 113-27.

Fernandes, Nuno. 2020. Economic Effects of Coronavirus Outbreak (COVID-19) on the World Economy. Available online: http: / / dx.doi.org/10.2139/ssrn.3557504 (accessed on 7 January 2021).

Graafland, Johan J. 2002. Sourcing ethics in the textile sector. The case of C\&A. Business Ethics. A European Review 11: $282-94$.

Gummesson, Evert. 1997. Relationship marketing as a paradigm shift: Some conclusions from the 30R approach. Management Decision 35: 267-72. [CrossRef]

Hendriksz, Vivian. 2017. Boohoo, Asos \& Misguided Pave the Way for Ultrafast Fashion. Available online: https://fashionunited.uk/ news/fashion/boohoo-asos-missguided-pave-the-way-for-ultrafastfashion/2017052424625 (accessed on 6 January 2021).

Henson, Robin K., and J. Kyle Roberts. 2006. Use of exploratory factor analysis in published research: Common errors and some comment on improved practice. Educational and Psychological Measurement 66: 393-416. [CrossRef]

Hines, Tony, and Pauric McGowan. 2005. Supply chain strategies in the UK fashion industry-The rhetoric of partnership and power. The International Entrepreneurship and Management Journal 1: 519-37. [CrossRef]

Hyvonen, Saara. 1983. Coordination and Cooperation in Vertical Marketing Systems, a Model Verification. Helsinki: The Helsinki School of Economics and Business Administration.

Inditex Annual Report. 2019. Available online: https://www.inditex.com/investors/investor-relations/results-and-presentations (accessed on 17 January 2021).

Inditex. 2020. Inditex: Interim Nine Months 2020 Results. Available online: https://www.inditex.com/documents/10279/648111 /INDITEX-Interim+9M2020+Results.pdf/9d63b4b5-155b-fe44-dc54-39c018a171ac (accessed on 18 January 2021).

Inditex. 2021. Inditex: Code of Conduct for Manufacturers and Suppliers. Available online: https://www.inditex.com/documents/10 279/241035/Inditex+Code+of+Conduct+for+Manufacturers+and+Suppliers/e23dde6a-4b0e-4e16-a2aa-68911d3032e7 (accessed on 18 January 2021).

Inditex Official Website. 2021. Available online: www.inditex.com (accessed on 15 January 2021).

International Chamber of Commerce. 2020. ICC Force Majeure and Hardship Clauses (March 2020). Available online: https: / /iccwbo.org/publication/icc-force-majeure-and-hardship-clauses (accessed on 14 January 2021). 
International Labour Organization. 2020. COVID-19: Action in the Global Garment Industry. Call to Action. April 2020. Available online: https://www.ilo.org/wcmsp5/groups/public/---ed_dialogue/---dialogue/documents/statement/wcms_742371.pdf (accessed on 18 January 2021).

Lee, Hau L. 2002. Aligning supply chain strategies with product uncertainties. California Management Review 44: 105-19. [CrossRef]

McMaster, May, Charlie Nettleton, Christeen Tom, Belanda Xu, Cheng Cao, and Ping Qiao. 2020. Risk Management: Rethinking Fashion Supply Chain Management for Multinational Corporations in Light of the COVID-19 Outbreak. Journal of Risk and Financial Management 13: 173. Available online: https://www.mdpi.com/1911-8074/13/8/173 (accessed on 7 January 2021). [CrossRef]

McNeil, Lisa, and Rebeca Moore. 2015. Sustainable fashion consumption and the fast fashion conundrum: Fashionable consumers and attitudes to sustainability in clothing choice. International Journal of Consumer Studies 39: 212-22. [CrossRef]

Mentzer, John T., Soonhong Ming, and Zach G. Zacharia. 2000. The Nature of Interfirm Pattering in Supply Chain Management. Journal of Retailing 76: 549-68. [CrossRef]

Meyer, Christine Benedichte. 2001. A Case in Case Study Methodology. Field Method 13: 329-52. [CrossRef]

Moon, Ka-Leung Karen, Ji-yeon Lee, and Sze-yeung Charlotte Lai. 2017. Key drivers of an agile, collaborative fast fashion supply chain: Dongdaemun fashion market. Journal of Fashion Marketing and Management: International Journal 21: 278-97. [CrossRef]

Ozcan, Pinar, Suho Han, and Melissa E. Graebner. 2017. Single cases: The what, why, and how. In The Routledge Companion to Qualitative Research in Organization Studies. Edited by Raza A. Mir and Sanjay Jain. New York: Routledge, pp. 92-112.

Perry, Patsy, and Steve Wood. 2018. Exploring the international supply chain and corporate social responsibility: Cost, responsiveness, and ethical implications. In Logistics and Retail Management, 5th ed. Edited by John Fernie and Leigh Sparks. London: Kogan Page, pp. 98-128.

Pilarczyk, Bogdan, Maria Sławińska, and Henryk Mruk. 2001. Strategie Marketingowe Przedsiębiorstw Handlowych. Warszawa: Polskie Wydaw, Ekonomiczne.

Rashid, Yasir, Ammar Rashid, Muhammad Akib Warraich, Sana Sameen Sabir, and Ansar Waseem. 2019. Case Study Method: A Step-by-Step Guide for Business Researchers. International Journal of Qualitative Methods 18: 1-13. [CrossRef]

Reck, Robert F., and Brian G. Long. 1988. Purchasing a Competitive Weapon. Journal of Purchasing and Materials Management 24: 2-8. [CrossRef]

Ricchetti, Marco, and Roberta De Palma. 2020. Will COVID-19 Accelerate the Transition to a Sustainable Fashion Industry? United Nations Industrial Organization. October 8. Available online: https://www.unido.org/stories/will-covid-19-accelerate-transitionsustainable-fashion-industry (accessed on 11 January 2021).

Sales Intelligence. 2020. Sales Intelligence 2020 Report: Fashion Purchases in COVID-19 Times. How Covid-19 Pandemic Changed Consumers' Purchasing Habits in Fashion Industry. Available online: https://salesintelligence.pl/wp-content/uploads/2020/0 7/Raport_ecommerce_rynek_fashion_2020_Sales_Intelligence.pdf (accessed on 7 January 2021).

Shajahn, Shamsudeen. 2006. Relationship Marketing: Text Cases. New Deli: The Mc Graw Hill Companies.

Sirdeshmukh, Deepak, Jagdip Singh, and Barry Sabol. 2002. Consumer trust, value, and loyalty in relational exchanges. Journal of Marketing 66: 15-37. [CrossRef]

Stake, Robert. 1995. The Art of Case Research. Newbury Park: Sage Publications.

Stannack, Patrick, and Michael Jones. 1996. The Death of Purchasing Procedures. Eindhoven: PSERA.

Tellis, Winston M. 1997. Application of a Case Study Methodology. The Qualitative Report 3: 1-19. [CrossRef]

Turker, Duygu, and Ceren Altuntas. 2014. Sustainable supply chain management in the fast fashion industry: An analysis of corporate reports. European Management Journal 32: 837-49. [CrossRef]

Vereecke, Ann, and Steve Muylle. 2006. Performance improvement through supply chain collaboration in Europe. International Journal of Operations and Production Management 26: 1176-98. [CrossRef]

Wathe, Kenneth H., and Jan B. Heide. 2004. Relationship Governance in a Supply Chain Network. Journal of Marketing 68: 73-89. [CrossRef]

Weinswig, Deborah. 2017. Fast Fashion Speeding toward Ultrafast Fashion. Available online: https://coresight.com/research/fastfashion-speeding-toward-ultrafast-fashion/ (accessed on 6 January 2021).

Worker Rights Consortium. 2020. Force Majeure: How Global Apparel Brands Are Using the COVID-19 Pandemic to Stiff Suppliers and Abandon Workers. Available online: https://www.ecchr.eu/fileadmin/ECCHR_PP_FARCE_MAJEURE.pdf (accessed on 14 January 2021).

Worker Rights Consortium. 2021. Covid-19 Tracker: Which Brands Are Acting Responsibly toward Suppliers and Workers? Available online: https:/ / www.workersrights.org/issues/covid-19/tracker/ (accessed on 15 January 2021).

Ye, Ying, and Kwok Hung Lau. 2018. Designing a demand chain management framework under dynamic uncertainty: An exploratory study of the Chinese fashion apparel industry. Asia Pacific Journal of Marketing and Logistics 30: 198-234. [CrossRef]

Yin, Robert K. 1993. Applications of Case Study Research. Newbury Park: Sage Publishing.

Yin, Robert K. 2014. Case Study Research: Design and Methods, 5th ed. Thousand Oaks: Sage.

Zhang, Jingran, Sevilay Onal, and Sanchoy Das. 2017. Price differentiated channel switching in a fixed period fast fashion supply chain. International Journal of Production Economics 193: 31-39. [CrossRef] 